Article

\title{
A Multi-Parameter Approach for Apricot Texture Analysis
}

\author{
Séverine Gabioud Rebeaud *, Alice Jaylet, Pierre-Yves Cotter, Cédric Camps $₫$ and \\ Danilo Christen
}

Agroscope Research Center, 1964 Conthey, Switzerland; jayletalice@gmail.com (A.J.); pierre-yves.cotter@agroscope.admin.ch (P.-Y.C.); cedric.camps@agroscope.admin.ch (C.C.); danilo.christen@agroscope.admin.ch (D.C.)

* Correspondence: severine.gabioud@agroscope.admin.ch

Received: 4 March 2019; Accepted: 3 April 2019; Published: 9 April 2019

check for updates

\begin{abstract}
Apricots have a short storage life principally caused by a rapid softening, which increases the sensitivity of the fruit to mechanical damage, and to the development of fungal diseases. The current methods to assess fruit firmness give limited information on the evolution and the mechanisms of softening. With the aim of developing novel strategies to better monitor fruit softening, a multi-parameter approach measuring textural properties was evaluated and compared to a reference method whose results are obtained from a unique parameter. 'Goldrich' and 'Orangered ${ }^{\circledR}$, apricots were used in this study as representative cultivars with substantially different post-harvest behavior. The results showed that this multi-parametric approach allows detailed evaluation of the influence of storage conditions on apricots' textural properties. The correlations found between firmness values measured by the standard method and the multiple textural parameters obtained by the compression and the puncture tests on the fruit flesh had r-values ranging from 0.6 to 0.78 . Parameters related to the skin were, however, poorly correlated with the standard method, with r-values all below 0.4. Taken together, these results demonstrate that a multi-parameter approach allows a better understanding of how storage conditions influence the softening of apricots in a cultivar-specific manner.
\end{abstract}

Keywords: apricot; storage; texture; puncture test; compression test

\section{Introduction}

Consumer awareness of the quality of fresh fruit has increased remarkably in the past few years and consequently so has their demand for high-quality products. Apricots are appreciated by consumers for their taste, sweetness and flavor and are the third most produced stone fruit after plums and peaches [1]. In 2016, the world production of apricots reached 3.9 million tons and Turkey was the most important country of production followed by Uzbekistan, Iran and Algeria [1]. In Switzerland, domestic production represents ca. 7500 tons and $3.4 \mathrm{~kg}$ per person are consumed per year [2]. The consumption of apricots in Switzerland has increased during the last 10 years [2] as well as the pressure for a high commercial quality.

Besides color and appearance, flavor (taste and aroma), and nutritional value which are important attributes describing fruit quality and influencing consumer choices [3], texture is a key parameter influencing not only the acceptance of the fruit by consumers but also their suitability to postharvest manipulations such as transport, storage, conditioning and, therefore, their final commercial value on the market. This is particularly true for apricot fruit. As soft fruit are more susceptible to mechanical damage and disease, apricots are usually harvested at an early stage of maturity when they are still firm in order to maximize storage life and to reduce losses caused by physical damages through the 
entire supply chain $[4,5]$. Harvesting at an early maturity stage is particularly achieved when fruit are intended to long shipping time. However, according to Bruhn et al. [6], consumers are generally not satisfied by the texture properties and the low flavor of such fruits. The consumption of apricots would be enhanced if they could be harvested at an optimal maturity stage corresponding to a typical flavor and a good texture corresponding to the consumer's expectation [6].

Apricots are climacteric fruits [7] characterized by a rapid ripening and softening after harvest. This ripening process is highly influenced by ethylene, which displays a peak of production during the climacteric stage. An increase of respiration is also observed at the same time. The softening is cultivar dependent [8] and is highly influenced by maturity stage at harvest $[9,10]$, storage conditions such as temperature and relative humidity, and storage duration [11]. In order to reduce firmness loss of apricots after harvest, storing fruit at low temperature is an efficient method [12]. Decreasing $\mathrm{O}_{2}$ levels and increasing $\mathrm{CO}_{2}$ levels in the atmosphere by keeping the fruit under modified or controlled atmosphere can increase the storage life of apricots $[12,13]$. Many studies also showed that 1-MCP treatment can help to maintain apricot quality after harvest [14,15]. All these postharvest methods influence directly the texture properties of the apricots by slowing down the physiological processes leading to softening.

New methods are needed to better characterize the texture of apricots and understand the evolution of this parameter after harvest, according to the cultivar and the pre- and post-harvest factors. Sensory analyses are the best methods to evaluate texture parameters influencing the appreciation of the fruit by the consumers, such as hardness, juiciness or elasticity [3]. Such approaches are, however, time consuming, require the participation of a trained sensory panel, and are therefore expensive to conduct. Instrumental methods that are objective and rapid have been developed in order to evaluate the texture properties of fruit. Several commercial instruments are available to measure fruit firmness. A frequently used technique is the puncture test, which consists in measuring the force required to push a cylindrical probe into the fruit to a determined depth. Some devices such as the AGROSTA ${ }^{\circledR} 100$ (formerly Durofel DFT 100, Agrosta Sàrl, Serqueux, France) or the Effegi (Facchini srl, Alfonsine, Italy) are manual and have been widely used for the measurement of apricot firmness [16-19]. Such instruments are easy to use and the result is obtained quickly, but they provide only single dimension value (e.g., hardness). Moreover, the reproducibility of this method is hampered by the manual handling required. More complex analyses of textural attributes of fruit can be assessed using motorized instruments such as the Texture Analyser recording of complete force/displacement curves [20]. Multitest devices can be fitted with different probe types and different test types can be achieved (compression, puncture). Parameters are extracted from the force/displacement curves.

Many studies have been carried out on the textural properties of fruit such as apples, pears, peaches [21-25], but only little information is available on the texture of apricots. Some studies were reported on the impact of cooking on apricot texture [26-29]. Stanley et al. [9] assessed the influence of harvest maturity and cold storage on the firmness, mealiness and gel formation of apricots but only firmness was measured by an instrument, as mealiness and gel formation were determined by trained assessors.

Quantitative measurement of texture is essential to ensure an optimal commercial quality of apricots on the market and to characterize the mechanisms involved in the evolution of this parameter before and after harvest. Thanks to a better understanding of the textural properties of apricots and their changes as the fruit ripens, quality for the consumers could be improved and losses reduced along the entire supply chain. In this study, we evaluated the influence of cultivar, storage temperature and storage duration on the textural attributes of the apricots fruits. More specific objectives were to compare these multi-parameter approaches to the classical measurement of firmness performed with a manual device. 


\section{Materials and Methods}

\subsection{Fruit}

Apricots of 'Orangered ${ }^{\circledR \prime}$ and 'Goldrich' cultivars were harvested at commercial maturity stage in 2016 from experimental orchards in the region of Valais in Switzerland. Fruit were stored at three temperatures $\left(1,8\right.$ and $20^{\circ} \mathrm{C}$ ) under normal air conditions at $90 \%$ of relative humidity. After 3 days of storage at $20^{\circ} \mathrm{C}$ or 1 and 2 weeks of storage at 1 and $8{ }^{\circ} \mathrm{C}$, fruit texture was assessed. Measurements were performed on apricots at ambient temperature.

\subsection{Texture Measurements}

Homogeneous batches of 40 fruits per sample were used for the texture measurements. Compression tests on the whole fruit and puncture tests on fruit skin were performed on the same batches of 20 fruits. As measurements done with the AGROSTA ${ }^{\circledR} 100$ device and the puncture tests on fruit flesh caused significant changes in the texture of the apricots, separate batches of 10 fruits were used for these tests.

\subsubsection{Classical Firmness Measurements}

Firmness was determined on two opposite sides of apricots using an AGROSTA ${ }^{\circledR} 100$ device fitted with a $0.10 \mathrm{~cm}^{2}$ probe (Agrosta Sàrl, Serqueux, France). This method consists in measuring the force required to push a probe against the fruit to a maximal depth. Results were expressed as $\mathrm{DI}_{10}$ on a scale going from 0 (very soft) to 100 (very hard).

\subsubsection{Compression Test on Whole Fruit}

The whole fruit firmness was determined by a compression test using a TA-XTplus Texture Analyzer (Stable Micro Systems, Godalming, UK) fitted with a $75 \mathrm{~mm}$ diameter flat probe. Fruit were compressed at a speed of $2 \mathrm{~mm} / \mathrm{s}$ to a maximal deformation corresponding to $5 \%$ of fruit caliber. The force (expressed in Newton) was recorded for every step of displacement. 6 parameters identified as $F_{C}, E_{c}, W_{C}{ }^{1}, W_{c}{ }^{1}, \Delta W_{c}{ }^{1-2}$ and $D_{c}$ were computed from the force/deformation curves as illustrated on Figure $1 . \mathrm{F}_{\mathrm{C}}$ represents the maximal force applied to push the probe until the fruit deformation reaches $5 \%$ of the caliber. This first phase of the measurement corresponds to the 'compression'. The young's modulus, represented by $\mathrm{E}_{\mathrm{c}}$, is also known as 'elastic modulus' and corresponds to the slope from the origin to $\mathrm{F}_{\mathrm{c}}$. $\mathrm{E}_{\mathrm{c}}$ gives indications about the rigidity of the product. $\mathrm{W}_{\mathrm{c}}{ }^{1}$ is the mechanical work needed to compress $5 \%$ of the fruit caliber and represents the area under the curve up to $5 \mathrm{~mm}$ of deformation. The second phase, called "decompression" gives indications on the "elastic" properties of the fruit. $\mathrm{W}_{\mathrm{c}}{ }^{2}$ is the work measured during the decompression phase and represents the area under the curve going from 5 to $0 \mathrm{~mm}$ of deformation. $\Delta \mathrm{W}_{\mathrm{c}}{ }^{1-2}$ corresponds to the hysteresis and $\mathrm{D}_{\mathrm{c}}$ represents the plastic deformation.

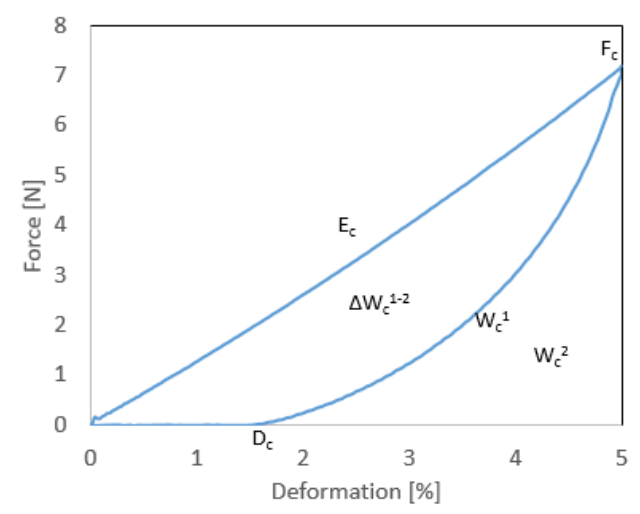

Figure 1. Force/deformation curve obtained from compression test and extracted parameters. 


\subsubsection{Puncture Test on Fruit Skin}

Puncture was performed on one side of each apricot using the TA-XTplus Texture Analyzer fitted with a needle probe of $2 \mathrm{~mm}$ diameter. The probe was moved at a speed of $20 \mathrm{~mm} / \mathrm{s}$ to a final depth of $3 \mathrm{~mm}$. The force (expressed in Newton) was recorded for every step of displacement and force/displacement curves included 294 data points were obtained for each measurement (Figure 2).

10 texture parameters were computed from the curves. $\mathrm{F}_{\mathrm{p}}{ }^{1}$ corresponds to the force needed to puncture the apricot skin. $\mathrm{D}_{\mathrm{p}}{ }^{1}$ represents the displacement of the probe at $\mathrm{F}_{\mathrm{p}}{ }^{1} . \mathrm{E}_{\mathrm{p}}{ }^{1}$ indicates the stiffness of the apricot and is the slope of the curve from the beginning of the measurement $(0 \mathrm{~mm})$ to $\mathrm{F}_{\mathrm{p}}{ }^{1} \cdot \mathrm{W}_{\mathrm{p}}{ }^{1}$ is the mechanical work needed to reach the rupture point and corresponds to the area under the curve from $0 \mathrm{~mm}$ to $\mathrm{F}_{\mathrm{p}}{ }^{1}$. In the second part of the curve, $\mathrm{F}_{\mathrm{p}}{ }^{2}$ was extracted as the minimal force occurring after the rupture of the skin. $\mathrm{D}_{\mathrm{p}}^{2}$ corresponds to the distance measured at $\mathrm{F}_{\mathrm{p}}{ }^{2}$. In the third part, a second peak occurred around $2.5 \mathrm{~mm}$. This peak represents the maximal force applied to move the probe in the flesh until a maximal depth of $3 \mathrm{~mm}$ and corresponds to $\mathrm{F}_{\mathrm{p}}{ }^{3}$. The displacement $\mathrm{D}_{\mathrm{p}}{ }^{3}$ indicates the position of the probe at $\mathrm{F}_{\mathrm{p}}{ }^{3}$. The slope between $\mathrm{F}_{\mathrm{p}}{ }^{2}$ and $\mathrm{F}_{\mathrm{p}}{ }^{3}\left(\mathrm{E}_{\mathrm{p}}{ }^{3}\right)$ and the mechanical work $\left(\mathrm{W}_{\mathrm{p}}{ }^{3}\right)$ needed to move the probe through the flesh were also computed.

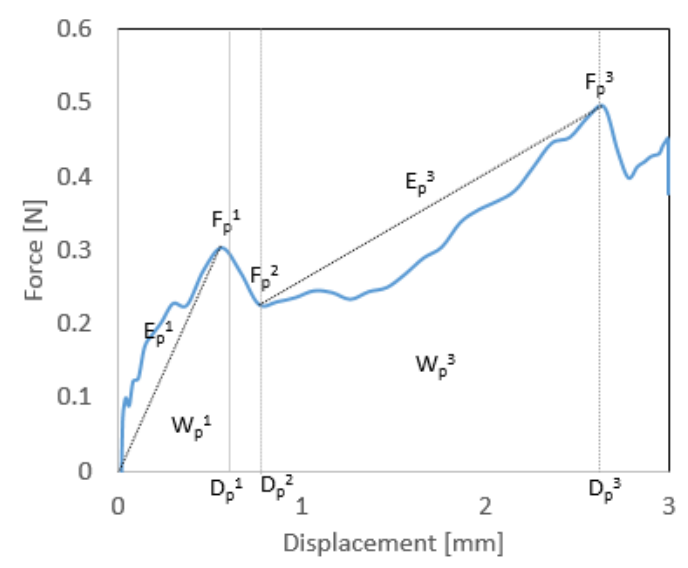

Figure 2. Force/displacement curve obtained from puncture test on fruit skin and extracted parameters.

\subsubsection{Puncture Test on Fruit Flesh}

Apricots were cut in half longitudinally and measurements were performed on a tissue slice of about $1.5 \mathrm{~cm}$ thick of one side. Two measurements were carried out on the opposite sides of each slice at the equatorial position. TA-XTplus Texture Analyzer was fitted with a stainless steel puncture probe of $2 \mathrm{~mm}$ diameter. The probe was moved at a speed of $10 \mathrm{~mm} / \mathrm{s}$ to a final depth of $8 \mathrm{~mm}$. The force (expressed in Newton) was recorded for every step of displacement and force/displacement curves including 172 data points were analyzed (Figure 3). Eight parameters were extracted from the curves. $\mathrm{F}_{\mathrm{p}}{ }^{1}$ represents the force at the first rupture point and $\mathrm{D}_{\mathrm{p}}{ }^{1}$ the displacement of the probe at $\mathrm{F}_{\mathrm{p}}{ }^{1} \cdot \mathrm{E}_{\mathrm{p}}{ }^{1}$ corresponds to the slope from $0 \mathrm{~mm}$ to $\mathrm{F}_{\mathrm{p}}{ }^{1}$ and $\mathrm{W}_{\mathrm{p}}{ }^{1}$ is the mechanical work to reach the first rupture point. The maximal force applied to move the probe into the flesh until $8 \mathrm{~mm}$ was extracted and is represented by $\mathrm{F}_{\mathrm{p}}{ }^{\max } . \mathrm{D}_{\mathrm{p}}{ }^{\max }$ correspond to the displacement of the probe at $\mathrm{F}_{\mathrm{p}}{ }^{\text {max }}$. The mean force between $\mathrm{F}_{\mathrm{p}}{ }^{1}$ and $\mathrm{F}_{\mathrm{p}}{ }^{\max }\left(\mathrm{F}_{\mathrm{p}}{ }^{\text {mean }}\right)$ was computed. $\mathrm{W}_{\mathrm{p}}{ }^{2}$ represents the mechanical work needed to move the probe through the flesh until $8 \mathrm{~mm}$. 


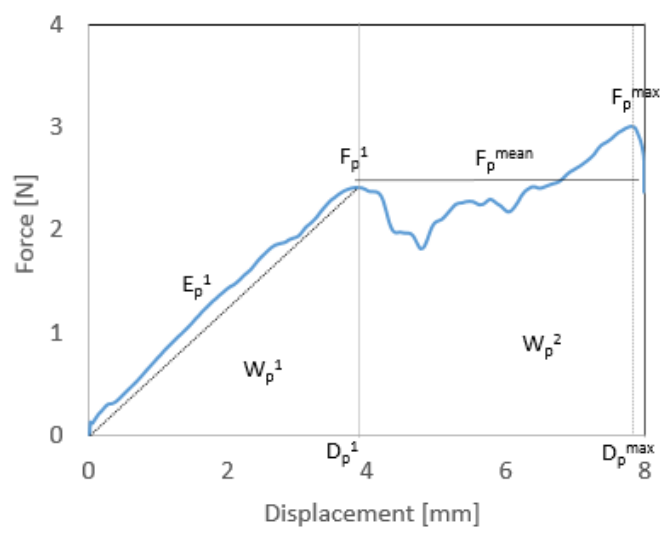

Figure 3. Force/displacement curve obtained from puncture test on fruit flesh and extracted parameters.

\subsection{Data Analyses}

Texture parameters were computed from each curve with the Texture Exponent Software (Version 6, Stable Micro Systems, Godalming, UK). Statistical analyses were achieved using the software XLSTAT (Version 2018.1, Addinsoft, Paris, France) and R (Version 3.5.1, R Development Core Team, Vienna, Austria).

Multivariate analyses were first performed on the parameters (compression tests) and on the whole curves (puncture tests) to evaluate the efficiency of the texture measurements to discriminate the different storage conditions. Principal component analyses (PCA) on normalized data from the whole force/displacement curves allowed the influence of storage conditions on the skin and flesh texture of the tested fruits to be explored. Then, the most significant textural parameters were chosen based on the results of the discriminant analyses (DA) computed from normalized data to perform analyses of variance (ANOVA, $p \leq 0.05$ ). The influence of storage conditions on these parameters was evaluated based on Tukey's multiple range test. Finally, Pearson's correlation coefficient $(p \leq 0.05)$ were computed to evaluate the relationships between the different methods. As the measurements were performed on different fruits, correlation coefficients were calculated using the mean values of each test.

\section{Results}

\subsection{Texture Variability Related to Storage Temperature and Duration}

\subsubsection{Classical Firmness Measurement}

Firmness measurement using an AGROSTA ${ }^{\circledR} 100$ device showed that storing apricots at $1{ }^{\circ} \mathrm{C}$ strongly delayed softening (Figure 4). The behavior of the two cultivars during storage at 1 and $8{ }^{\circ} \mathrm{C}$ was slightly different: the firmness of 'Goldrich' decreased gradually up to two weeks of storage, whereas a significant softening was observed only during the first week of storage of 'Orangered ${ }^{\circledR}$ '. Firmness value of this cultivar then remained constant during the additional week of storage at 1 and $8{ }^{\circ} \mathrm{C}$. 


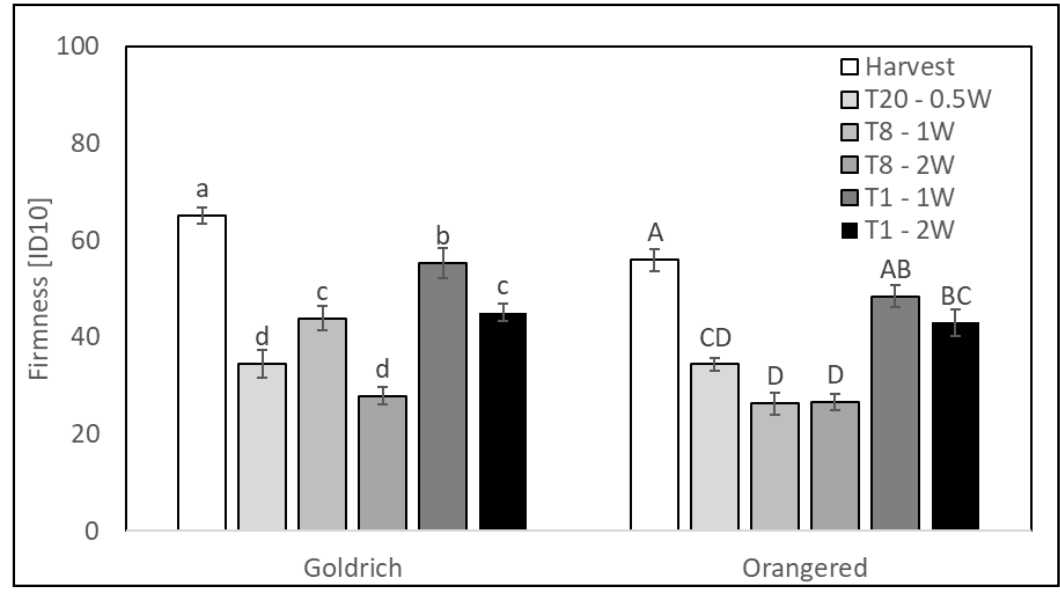

Figure 4. Influence of storage temperature on firmness measured by AGROSTA ${ }^{\circledR} 100$ device on 'Goldrich' and 'Orangered ${ }^{\circledR \prime}$ apricots stored at $1{ }^{\circ} \mathrm{C}(\mathrm{T} 1), 8{ }^{\circ} \mathrm{C}(\mathrm{T} 8)$ and $20{ }^{\circ} \mathrm{C}$ (T20) during $0.5,1$ or 2 weeks $(\mathrm{W})$. Means with the same letters are not significantly different at $p \leq 0.05$ in Tukey's multiple range test.

\subsubsection{Compression Test on Whole Fruit}

In contrast to the firmness measurements performed with AGROSTA ${ }^{\circledR} 100$ giving one parameter as a result, force/deformation curves were obtained by the compression tests achieved with the TA-XTplus Texture Analyzer. Based on the 6 parameters extracted from these curves (Figure 1), discriminant analyses (DA) were calculated separately for each cultivar. Temperature and storage duration were the qualitative groups taken for samples discrimination. The mean percentage of correctly classified samples was comparable for both cultivars (Table 1); $75 \%$ (group ' 2 weeks') and $80 \%$ (group ' 1 week') of 'Goldrich' apricots stored at $1{ }^{\circ} \mathrm{C}$ were correctly classified, whereas only $55 \%$ (group ' 2 weeks') and $45 \%$ (group ' 1 week') were correctly identified at $8{ }^{\circ} \mathrm{C}$. Inversely, the percentage of correctly classified 'Orangered ${ }^{\circledR}$ ' fruit was higher at $8^{\circ} \mathrm{C}$ than at $1{ }^{\circ} \mathrm{C}$ (Table 1), indicating that the influence of temperature on the textural parameters measured by compression test was different depending on the cultivar. As shown in Table 2, $\Delta \mathrm{W}_{\mathrm{c}}{ }^{1-2}$ was the most significant textural parameter correlated with the first factor (F1) of the DA performed on 'Goldrich' fruit, followed by $\mathrm{W}_{\mathrm{c}}{ }^{1}, \mathrm{~F}_{\mathrm{c}}$ and $\mathrm{E}_{\mathrm{c}}$ (r-values of $-0.95,-0.90,-0.87$ and -0.85 respectively). In the case of 'Orangered ${ }^{\circledR}, \mathrm{W}_{\mathrm{c}}{ }^{2}$ had the best correlation with $\mathrm{F} 1$ followed by $\mathrm{F}_{\mathrm{c}}, \mathrm{E}_{\mathrm{c}}$ and $\mathrm{W}_{\mathrm{c}}{ }^{1}$ ( $\mathrm{r}$ values of $-0.91,-0.84,-0.83$ and -0.82 respectively). The second factor (F2) was mainly correlated with $D_{c}$ for 'Goldrich' and $\Delta W_{c}{ }^{1-2}$ for 'Orangered ${ }^{\circledR} . F_{c}, W_{c}{ }^{1}$ and $E_{c}$ contributed in a similar way to the discrimination of the samples for both cultivars, but the most significant parameters were different $\left(\Delta \mathrm{W}_{\mathrm{c}}{ }^{1-2}\right.$ respectively $\mathrm{W}_{\mathrm{c}}{ }^{2}$ in the case of ‘Goldrich' resp. 'Orangered ${ }^{\circledR \prime}$ ).

Table 1. Percentage of correctly classified 'Goldrich' and 'Orangered ${ }^{\circledR \prime}$ apricots according to storage temperature and duration obtained with discriminant analyses (DA) performed on 6 parameters extracted from force/deformation curves from compression test $\left(\mathrm{F}_{\mathrm{C}}, \mathrm{W}_{\mathrm{c}}{ }^{1}, \mathrm{E}_{\mathrm{C}}, \mathrm{D}_{\mathrm{c}}, \mathrm{W}_{\mathrm{c}}{ }^{2}\right.$ and $\left.\Delta \mathrm{W}_{\mathrm{c}}{ }^{1-2}\right)$.

\begin{tabular}{cccc}
\hline Storage Temperature & Weeks of Storage & Goldrich & Orangered $^{\circledR}$ \\
\hline Harvest & 0 & $73.7 \%$ & $75.0 \%$ \\
20 & 0.5 & $73.7 \%$ & $60.0 \%$ \\
8 & 1 & $45.0 \%$ & $78.9 \%$ \\
& 2 & $55.0 \%$ & $81.3 \%$ \\
1 & 1 & $80.0 \%$ & $45.0 \%$ \\
& 2 & $75.0 \%$ & $40.0 \%$ \\
\hline Mean & $66.9 \%$ & $62.6 \%$ \\
\hline
\end{tabular}


Table 2. Correlation coefficients $(p \leq 0.05)$ between the first two discriminant scores (F1 and F2) and texture parameters extracted from the force/deformation curves.

\begin{tabular}{llcccccc}
\hline & & $\mathbf{F}_{\mathbf{c}}$ & $\mathbf{W}_{\mathbf{c}}{ }^{\mathbf{1}}$ & $\mathbf{E}_{\mathbf{c}}$ & $\mathbf{D}_{\mathbf{c}}$ & $\mathbf{W}_{\mathbf{c}}{ }^{2}$ & $\Delta \mathbf{W}_{\mathbf{c}}{ }^{\mathbf{1 - 2}}$ \\
\hline Goldrich & $\mathrm{F} 1$ & -0.87 & -0.90 & -0.85 & -0.22 & -0.78 & -0.95 \\
& $\mathrm{~F} 2$ & -0.47 & -0.42 & -0.48 & 0.80 & -0.62 & -0.26 \\
\hline Orangered $^{\circledR}$ & $\mathrm{F} 1$ & -0.84 & -0.82 & -0.83 & 0.77 & -0.91 & -0.71 \\
& $\mathrm{~F} 2$ & -0.32 & -0.35 & -0.34 & 0.21 & -0.23 & -0.45 \\
\hline
\end{tabular}

To understand the influence of temperature and storage duration on textural parameters measured by the compression test, analyses of variance were performed separately for each cultivar (Table 3). The maximal force applied to move the probe until the fruit's deformation reached $5 \%$ of fruit caliber $\left(\mathrm{F}_{\mathrm{c}}\right)$ decreased with storage duration. Similar results were observed for $\mathrm{E}_{\mathrm{c}}$ and $\mathrm{W}_{\mathrm{c}}{ }^{1}$ (data not shown). A stronger force was required to move the probe at $1{ }^{\circ} \mathrm{C}$ compared to $8{ }^{\circ} \mathrm{C}$. This was particularly true for 'Orangered ${ }^{\circledR \prime}$. A higher plastic deformation $\left(D_{c}\right)$ was observed on 'Goldrich' fruit stored at $20^{\circ} \mathrm{C}$, and for both cultivar after a storage at $8{ }^{\circ} \mathrm{C}$ during 2 weeks. No influence of a 1 week of storage at $1{ }^{\circ} \mathrm{C}$ was observed on $\mathrm{D}_{\mathrm{c}}$ for both cultivar. Hysteresis decreased during storage, indicating a reduction of fruit elasticity. This effect was more pronounced on fruit stored at $8{ }^{\circ} \mathrm{C}$.

Table 3. Influence of storage temperature and duration on $F_{c}, W_{c}{ }^{2}, \Delta W_{c}{ }^{1-2}$ and $D_{c}$. Means with the same letters in a column are not significantly different at $p \leq 0.05$ in Fisher's multiple range test. G: 'Goldrich' and O: ‘Orangered ${ }^{\circledR}$.

\begin{tabular}{|c|c|c|c|c|c|c|c|c|c|}
\hline \multirow{2}{*}{$\begin{array}{c}\text { Storage } \\
\text { Temperature }\end{array}$} & \multirow{2}{*}{$\begin{array}{l}\text { Weeks of } \\
\text { Storage }\end{array}$} & \multicolumn{2}{|c|}{$F_{c}(N)$} & \multicolumn{2}{|c|}{$\mathrm{Wc}^{2}(\mathrm{~N} \cdot \mathrm{mm})$} & \multicolumn{2}{|c|}{$\Delta \mathrm{W}_{\mathrm{c}}{ }^{1-2}(\mathrm{~N} \cdot \mathrm{mm})$} & \multicolumn{2}{|c|}{$D_{c}(\%)$} \\
\hline & & G & $\mathrm{O}$ & G & $\mathrm{O}$ & G & O & G & $\mathrm{O}$ \\
\hline Harvest & 0 & $5.80 \mathrm{a}$ & $5.84 \mathrm{a}$ & $2.43 \mathrm{a}$ & $2.84 \mathrm{a}$ & $3.56 \mathrm{a}$ & $3.11 \mathrm{a}$ & $1.78 \mathrm{~cd}$ & $1.48 \mathrm{c}$ \\
\hline 20 & 0.5 & $3.91 \mathrm{~b}$ & $3.75 \mathrm{bc}$ & $1.40 \mathrm{~b}$ & $1.51 \mathrm{bc}$ & $2.73 \mathrm{~b}$ & $2.36 \mathrm{~b}$ & $2.14 \mathrm{a}$ & $1.83 \mathrm{~b}$ \\
\hline \multirow[t]{2}{*}{8} & 1 & $2.63 \mathrm{c}$ & $3.03 c$ & $1.11 \mathrm{c}$ & $1.29 \mathrm{c}$ & $1.68 \mathrm{~d}$ & $1.82 \mathrm{c}$ & $1.84 \mathrm{c}$ & $1.72 \mathrm{~b}$ \\
\hline & 2 & $2.15 \mathrm{c}$ & $2.00 \mathrm{~d}$ & $0.79 \mathrm{~d}$ & $0.74 \mathrm{~d}$ & $1.38 \mathrm{de}$ & $1.23 \mathrm{~d}$ & $2.00 \mathrm{~b}$ & $2.04 \mathrm{a}$ \\
\hline \multirow[t]{2}{*}{1} & 1 & $3.84 \mathrm{~b}$ & $5.41 \mathrm{a}$ & $1.53 \mathrm{~b}$ & $2.47 \mathrm{a}$ & $2.19 \mathrm{c}$ & $3.14 \mathrm{a}$ & $1.82 \mathrm{~cd}$ & $1.56 \mathrm{c}$ \\
\hline & 2 & $2.32 \mathrm{c}$ & $4.23 \mathrm{~b}$ & $0.96 \mathrm{~cd}$ & $1.83 \mathrm{~b}$ & $1.29 \mathrm{e}$ & $2.49 \mathrm{~b}$ & $1.71 \mathrm{~d}$ & $1.76 \mathrm{~b}$ \\
\hline
\end{tabular}

\subsubsection{Puncture Test on the Skin}

Needle tests were performed to characterize textural properties of the skin and the first layers of the flesh, as well as to determine the influence of storage conditions on these tissues. Principal component analyses (PCA) were first performed on whole force/displacement curves issued form the tests to explore the variability of the curves as a function of the storage temperature and duration. $90.2 \%$, respectively $89.4 \%$ of the variation was explained by the two first components (PC1 and PC2) for 'Goldrich' resp. 'Orangered ${ }^{\circledR \prime}$ cultivars (Figure 5). PC1 of both PCA accounted for $75.6 \%$ and $77.1 \%$ respectively of the variation and were mainly correlated with the second part of the curve corresponding to the first layers of the flesh (ca. 0.5 to $3 \mathrm{~mm}$ ). PC2 accounted for $14.6 \%$ and $12.3 \%$ respectively of the variation and showed a high correlation with the first part of the curve corresponding to the skin (ca. 0 to $0.3 \mathrm{~mm}$ ). Concerning 'Goldrich', fruit at harvest and stored at $1{ }^{\circ} \mathrm{C}$ during 1 week were discriminated from apricots stored at $1{ }^{\circ} \mathrm{C}$ during 2 weeks and at $8{ }^{\circ} \mathrm{C}$ during 1 week and were positively correlated with PC1 (Figure 5a, b). Storing fruit at room temperature for a short time or at $8{ }^{\circ} \mathrm{C}$ but for a longer time induced changes in the texture of the first layers of the flesh of this cultivar. These results suggest that textural changes in the first layers of the flesh occurred more rapidly in 'Goldrich' apricots stored at 8 and $20^{\circ} \mathrm{C}$ compared to $1{ }^{\circ} \mathrm{C}$. In the case of 'Orangered ${ }^{\circledR}$, separation between the samples was less obvious. Only fruit stored at $8{ }^{\circ} \mathrm{C}$ during 2 weeks showed a strong positive correlation with the first axis. $\mathrm{PC} 2$, which was highly correlated with skin texture properties (Figure $5 \mathrm{~d}$ ) was negatively correlated with the samples measured at harvest. All other samples were not discriminated on this component, which indicates that storage influenced in a similar manner the textural properties of the skin, independent of the temperature and the duration. 

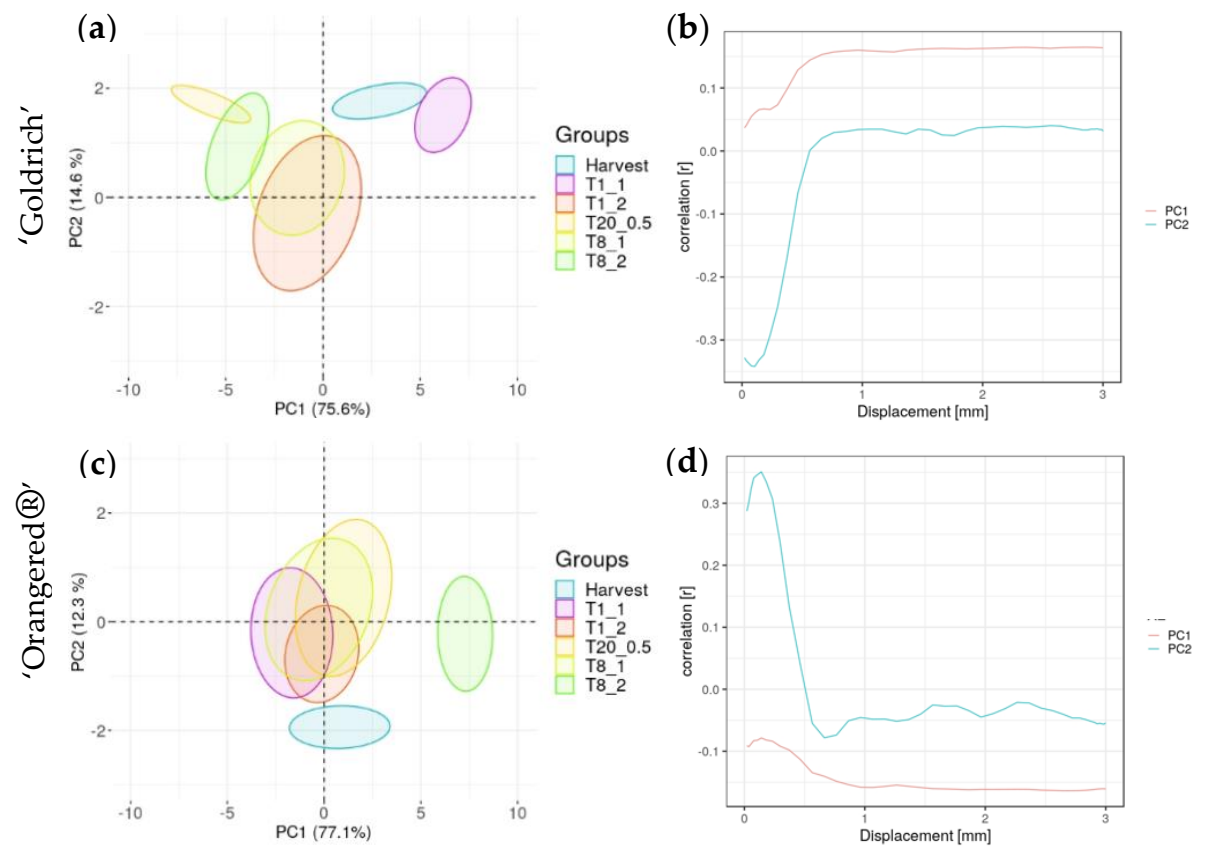

Figure 5. Principal component analysis (PCA) performed on force/displacement curves issued from puncture tests of the skin of $(\mathbf{a}, \mathbf{b})$ 'Goldrich' and $(\mathbf{c}, \mathbf{d})$ 'Orangered ${ }^{\circledR \prime}$ apricots at harvest and after 0.5 week at $20^{\circ} \mathrm{C}\left(\mathrm{T} 20 \_0.5\right), 1$ and 2 weeks at $1{ }^{\circ} \mathrm{C}$ and $8{ }^{\circ} \mathrm{C}$ (T8_1, T8_2, T1_1 and T1_2). (a,c): PCA scores, (b,d): PCs loadings.

DA were performed based on the 10 parameters extracted from the force/distance curves obtained by the puncture tests (Table 4). The mean percentage of correctly classified samples was comparable for both cultivars (53.4\% for 'Goldrich' and $54.9 \%$ for 'Orangered ${ }^{\circledR \prime}$ ), albeit low. 'Goldrich' fruit stored at $20{ }^{\circ} \mathrm{C}$ during 0.5 week were better discriminated compared to the other samples. For 'Orangered ${ }^{\circledR \prime}$, storing fruit at $8^{\circ} \mathrm{C}$ during 2 weeks leaded to a higher percentage of correct classified samples. The textural parameters $\mathrm{W}_{\mathrm{p}}{ }^{3}, \mathrm{~F}_{\mathrm{p}}{ }^{3}, \mathrm{~F}_{\mathrm{p}}{ }^{2}, \mathrm{D}_{\mathrm{p}}{ }^{3}$ and $\mathrm{F}_{\mathrm{p}}{ }^{1}$ had the higher correlations with the F1 DA factor for both cultivars (Table 5). These 5 textural parameters were, therefore, chosen to perform ANOVA and to evaluate in more details the changes of these parameters under the three tested storage temperatures (Table 6). The lower the temperature was, the higher were the force needed to puncture the skin and the mechanical work needed to move the probe through the flesh of 'Goldrich' apricots $\left(\mathrm{F}_{\mathrm{p}}{ }^{1}, \mathrm{~W}_{\mathrm{p}}{ }^{3}\right)$. For 'Orangered ${ }^{\circledR}$ ' fruit, smaller differences were observed on these two parameters between the different storage conditions. The minimal force measured after the rupture of the skin $\left(\mathrm{F}_{\mathrm{p}}{ }^{2}\right)$ and the maximal force applied to move the probe into the flesh until a maximal depth of $3 \mathrm{~mm}$ were significantly comparable at harvest and after 1 week at $1{ }^{\circ} \mathrm{C}$ in the case of 'Goldrich' cultivar. Concerning 'Orangered ${ }^{\circledR \prime}$ ', a significant decrease of $\mathrm{F}_{\mathrm{p}}{ }^{2}$ and $\mathrm{F}_{\mathrm{p}}{ }^{3}$ was observed after 2 weeks at $8{ }^{\circ} \mathrm{C}$ compared to harvest, but not under the other storage conditions. Interestingly, the maximal force applied to move the probe in the flesh until a depth of $3 \mathrm{~mm}$ just after the rupture of the skin $\left(\mathrm{F}_{\mathrm{p}}{ }^{3}\right)$ was about 5 times higher for 'Orangered ${ }^{\circledR \prime}$ apricots compared to the 'Goldrich'. 'Goldrich' fruit, however, needed a slightly higher force to puncture the skin. 
Table 4. Percentage of correctly classified 'Goldrich' and 'Orangered ${ }^{\circledR \prime}$ apricots according to storage temperature and duration obtained with DA performed on 10 parameters extracted from force/distance curves from puncture test.

\begin{tabular}{cccc}
\hline \multirow{2}{*}{ Storage Temperature } & \multirow{2}{*}{ Weeks of Storage } & \multicolumn{2}{c}{ Parameters Needle Test } \\
\cline { 3 - 4 } & & Goldrich & Orangered $^{\circledR}$ \\
\hline Harvest & 0 & $60.0 \%$ & $70.6 \%$ \\
20 & 0.5 & $77.8 \%$ & $30.0 \%$ \\
8 & 1 & $45.0 \%$ & $42.1 \%$ \\
& 2 & $36.8 \%$ & $88.2 \%$ \\
1 & 1 & $55.0 \%$ & $50.0 \%$ \\
Mean & 2 & $47.4 \%$ & $55.0 \%$ \\
& & $53.4 \%$ & $54.9 \%$ \\
\hline
\end{tabular}

Table 5. Correlation coefficients $(p \leq 0.05)$ between discriminant scores (F1 and F2) and texture parameters extracted from the force/deformation curves.

\begin{tabular}{lccccccccccc}
\hline & & $\mathbf{F}_{\mathbf{p}}{ }^{\mathbf{1}}$ & $\mathbf{E}_{\mathbf{p}}{ }^{\mathbf{1}}$ & $\mathbf{W}_{\mathbf{p}}{ }^{\mathbf{1}}$ & $\mathbf{D}_{\mathbf{p}}{ }^{\mathbf{1}}$ & $\mathbf{F}_{\mathbf{p}}{ }^{2}$ & $\mathbf{D}_{\mathbf{p}}{ }^{2}$ & $\mathbf{F}_{\mathbf{p}}{ }^{\mathbf{3}}$ & $\mathbf{E}_{\mathbf{p}}{ }^{\mathbf{2}}$ & $\mathbf{D}_{\mathbf{p}}{ }^{\mathbf{3}}$ & $\mathbf{W}_{\mathbf{p}}{ }^{\mathbf{3}}$ \\
\hline Goldrich & $\mathrm{F} 1$ & 0.68 & 0.11 & 0.38 & -0.06 & 0.82 & -0.25 & 0.92 & 0.12 & 0.81 & 0.96 \\
& $\mathrm{~F} 2$ & -0.35 & -0.63 & 0.55 & 0.87 & 0.24 & 0.51 & 0.24 & 0.15 & -0.01 & 0.10 \\
\hline Orangered $^{\circledR}$ & $\mathrm{F} 1$ & -0.53 & -0.38 & -0.02 & 0.42 & -0.69 & 0.59 & -0.70 & -0.29 & -0.78 & -0.78 \\
& $\mathrm{~F} 2$ & 0.14 & 0.28 & -0.37 & -0.54 & -0.45 & -0.17 & -0.33 & -0.14 & -0.14 & -0.20 \\
\hline
\end{tabular}

Table 6. Influence of storage temperature and duration on $\mathrm{F}_{\mathrm{p}}{ }^{1}, \mathrm{~F}_{\mathrm{p}}{ }^{2}, \mathrm{~F}_{\mathrm{p}}{ }^{3}, \mathrm{D}_{\mathrm{p}}{ }^{3}$ and $\mathrm{W}_{\mathrm{p}}{ }^{3}$. Means with the same letters in a column are not significantly different at $p \leq 0.05$ in Fisher's multiple range test. G: 'Goldrich' and O: ‘Orangered ${ }^{\circledR}$.

\begin{tabular}{|c|c|c|c|c|c|c|c|c|c|c|c|}
\hline \multirow{2}{*}{$\begin{array}{c}\text { Storage } \\
\text { Temperature }\end{array}$} & \multirow{2}{*}{$\begin{array}{l}\text { Weeks of } \\
\text { Storage }\end{array}$} & \multicolumn{2}{|c|}{$F_{p}{ }^{1}(N)$} & \multicolumn{2}{|c|}{$\mathrm{F}_{\mathrm{p}}^{2}(\mathrm{~N})$} & \multicolumn{2}{|c|}{$\mathrm{F}_{\mathrm{p}}{ }^{3}(\mathrm{~N})$} & \multicolumn{2}{|c|}{$\mathrm{D}_{\mathrm{p}}{ }^{3}(\mathrm{~mm})$} & \multicolumn{2}{|c|}{$\mathrm{W}_{\mathrm{p}}^{3}(\mathrm{~N} \cdot \mathrm{mm})$} \\
\hline & & G & $\mathrm{O}$ & G & $\mathrm{O}$ & G & $\mathrm{O}$ & $G$ & $\mathrm{O}$ & G & $\mathrm{O}$ \\
\hline Harvest & 0 & $0.282 \mathrm{c}$ & $0.240 \mathrm{bc}$ & $0.190 \mathrm{a}$ & $0.142 \mathrm{a}$ & $0.062 \mathrm{a}$ & $0.338 \mathrm{ab}$ & $0.425 \mathrm{~b}$ & $0.347 \mathrm{~b}$ & $0.767 \mathrm{~b}$ & $0.597 \mathrm{~b}$ \\
\hline 20 & 0.5 & $0.222 \mathrm{~d}$ & $0.277 \mathrm{ab}$ & $0.108 \mathrm{~d}$ & $0.141 \mathrm{a}$ & $0.044 \mathrm{~b}$ & $0.334 \mathrm{ab}$ & $0.220 \mathrm{c}$ & $0.395 \mathrm{~b}$ & $0.413 \mathrm{~d}$ & $0.658 \mathrm{ab}$ \\
\hline \multirow[t]{2}{*}{8} & 1 & $0.284 \mathrm{bc}$ & $0.285 a$ & $0.148 \mathrm{bc}$ & $0.135 \mathrm{a}$ & $0.033 \mathrm{~b}$ & $0.313 \mathrm{~b}$ & $0.366 \mathrm{~b}$ & $0.363 \mathrm{~b}$ & $0.618 \mathrm{c}$ & $0.616 \mathrm{~b}$ \\
\hline & 2 & $0.264 \mathrm{c}$ & $0.204 \mathrm{c}$ & $0.128 \mathrm{~cd}$ & $0.061 \mathrm{~b}$ & $0.045 \mathrm{~b}$ & $0.149 \mathrm{c}$ & $0.267 \mathrm{c}$ & $0.107 \mathrm{c}$ & $0.501 \mathrm{~d}$ & 0.272 c \\
\hline \multirow[t]{2}{*}{1} & 1 & $0.330 \mathrm{a}$ & $0.279 \mathrm{ab}$ & $0.216 \mathrm{a}$ & $0.153 \mathrm{a}$ & $0.065 \mathrm{a}$ & $0.382 \mathrm{a}$ & $0.548 \mathrm{a}$ & $0.496 \mathrm{a}$ & $0.923 \mathrm{a}$ & $0.744 \mathrm{a}$ \\
\hline & 2 & $0.313 \mathrm{ab}$ & $0.266 \mathrm{ab}$ & $0.157 \mathrm{~b}$ & $0.164 \mathrm{a}$ & $0.044 \mathrm{~b}$ & $0.340 \mathrm{ab}$ & $0.411 \mathrm{~b}$ & $0.404 \mathrm{ab}$ & $0.702 \mathrm{bc}$ & $0.662 \mathrm{ab}$ \\
\hline
\end{tabular}

\subsubsection{Puncture Test on the Flesh}

PCA calculated on the whole force/displacement curves showed that $90.9 \%$ and $91.2 \%$, respectively, of the variation was explained by the two first components for 'Goldrich' resp. 'Orangered ${ }^{\circledR \prime}$ cultivars (Figure 6). Despite good discrimination of the fruit on the two first components, the discrimination of the different groups was poor, in particular for fruit at harvest or stored at $1{ }^{\circ} \mathrm{C}$ for 1 or 2 weeks and at $8{ }^{\circ} \mathrm{C}$ for 1 week. Storage of both apricot cultivars at $20^{\circ} \mathrm{C}$ or at $8{ }^{\circ} \mathrm{C}$ during 2 weeks induced more changes in the flesh than the other groups, as illustrated by the discrimination on PC1. DA were then performed on the 8 extracted parameters from the force/displacement curves (data not shown). The 4 most correlated factors with F1 were then chosen to perform ANOVA (Table 7). Samples measured at harvest and after 1 week of storage at $1{ }^{\circ} \mathrm{C}$ showed similar values of $\mathrm{F}_{\mathrm{p}}{ }^{\mathrm{max}}, \mathrm{F}_{\mathrm{p}}{ }^{1}$ and $\mathrm{W}_{\mathrm{p}}{ }^{\text {tot }}$, indicating that the forces needed to move the probe into the flesh $\left(\mathrm{F}_{\mathrm{p}}{ }^{\mathrm{max}}\right.$ and $\left.\mathrm{F}_{\mathrm{p}}{ }^{1}\right)$ and the mechanical work needed to reach the maximal force decreased at higher temperature of storage or after a 2-week storage duration. However, this was only true for the cultivar 'Goldrich', whereas for 'Orangered ${ }^{\circledR \prime}$, diminution of these parameters was already significant after 1 week at $1{ }^{\circ} \mathrm{C}$, indicating that storage at $1{ }^{\circ} \mathrm{C}$ influenced textural properties of the flesh in a different manner according to the cultivar. Interestingly, the different forces $\left(\mathrm{F}_{\mathrm{p}}{ }^{\max }, \mathrm{F}_{\mathrm{p}}{ }^{1}\right.$ and $\left.\mathrm{F}_{\mathrm{p}}{ }^{\text {mean }}\right)$ and the mechanical work to reach $\mathrm{F}_{\mathrm{p}}$ max decreased in a similar way at $20^{\circ} \mathrm{C}$ during 0.5 week and at $8{ }^{\circ} \mathrm{C}$ during 2 weeks for both cultivars. The same observation was done for the storage at $8{ }^{\circ} \mathrm{C}$ for 1 week and at $1{ }^{\circ} \mathrm{C}$ for 2 weeks. 
(a)

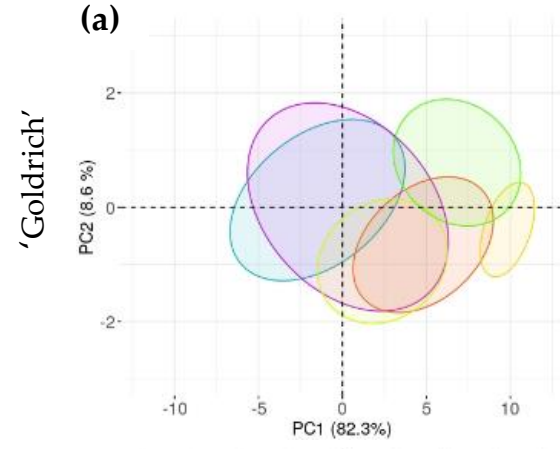

(c)

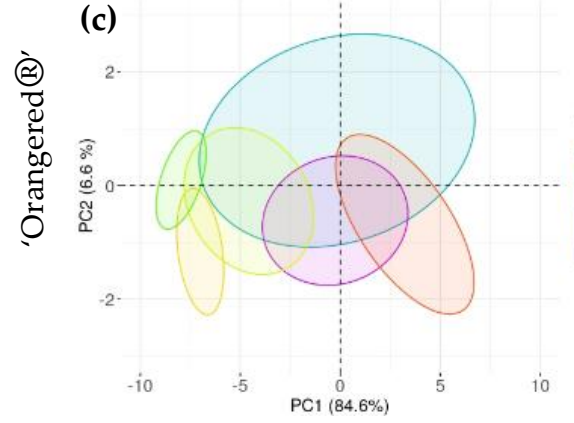

(b)

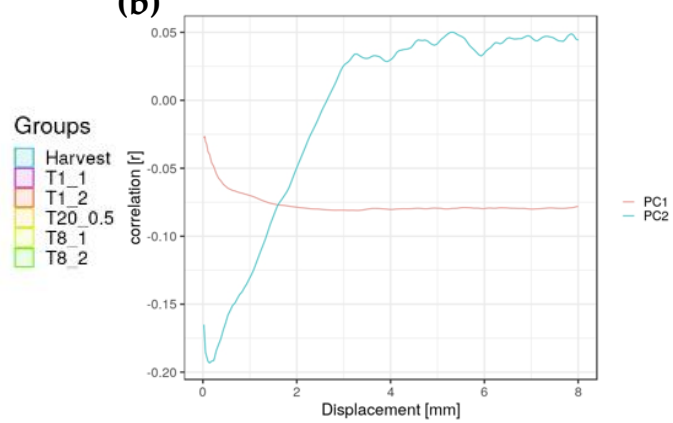

(d)

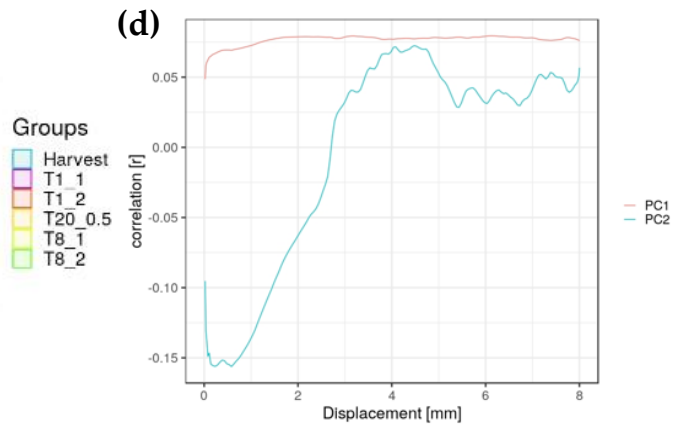

Figure 6. PCA performed on force/displacement curves issued from puncture tests of the flesh of $(\mathbf{a}, \mathbf{b})$ 'Goldrich' and (c,d) 'Orangered ${ }^{\circledR}$ ' apricots at harvest and after 0.5 week at $20^{\circ} \mathrm{C}$ (T20_0.5), 1 and 2 weeks at $1{ }^{\circ} \mathrm{C}$ and $8{ }^{\circ} \mathrm{C}\left(\mathrm{T} 8 \_1, \mathrm{~T} 8 \_2, \mathrm{~T} 1 \_1\right.$ and T1_2). (a,c): PCA scores, (b,d): PCs loadings.

Table 7. Influence of storage temperature and duration on $\mathrm{F}_{\mathrm{p}}{ }^{\max }, \mathrm{F}_{\mathrm{p}}{ }^{1}, \mathrm{~F}_{\mathrm{p}}$ mean and $\mathrm{W}_{\mathrm{p}}{ }^{\text {tot }}$. Means with the same letters in a column are not significantly different at $p \leq 0.05$ in Fisher's multiple range test. G: ‘Goldrich' and O: ‘Orangered ${ }^{\circledR}$.

\begin{tabular}{|c|c|c|c|c|c|c|c|c|c|}
\hline \multirow{2}{*}{$\begin{array}{c}\text { Storage } \\
\text { Temperature }\end{array}$} & \multirow{2}{*}{$\begin{array}{l}\text { Weeks of } \\
\text { Storage }\end{array}$} & \multicolumn{2}{|c|}{$\mathrm{F}_{\mathrm{p}}^{\max }(\mathrm{N})$} & \multicolumn{2}{|c|}{$F_{p}{ }^{1}(N)$} & \multicolumn{2}{|c|}{$\mathrm{F}_{\mathrm{p}}^{\text {mean }}(\mathrm{N})$} & \multicolumn{2}{|c|}{$\mathrm{W}_{\mathrm{p}}^{\text {tot }}(\mathrm{N} \cdot \mathrm{mm})$} \\
\hline & & G & O & G & O & G & $\mathrm{O}$ & G & O \\
\hline Harvest & 0 & $1.988 \mathrm{a}$ & $3.088 \mathrm{a}$ & $1.677 \mathrm{a}$ & $2.791 \mathrm{a}$ & $1.572 \mathrm{a}$ & $2.057 \mathrm{a}$ & $9.812 \mathrm{a}$ & $14.277 \mathrm{a}$ \\
\hline 20 & 0.5 & $0.477 \mathrm{c}$ & $0.988 \mathrm{~d}$ & $0.346 \mathrm{c}$ & $0.770 \mathrm{~d}$ & $0.317 \mathrm{~d}$ & $0.613 \mathrm{~cd}$ & $2.286 \mathrm{c}$ & $4.395 \mathrm{de}$ \\
\hline \multirow[t]{2}{*}{ 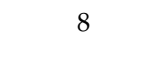 } & 1 & $1.397 \mathrm{~b}$ & $1.396 \mathrm{~cd}$ & $0.942 \mathrm{~b}$ & $1.134 \mathrm{~cd}$ & $0.940 \mathrm{c}$ & $1.005 \mathrm{bc}$ & $6.414 \mathrm{~b}$ & $6.978 \mathrm{~cd}$ \\
\hline & 2 & $0.687 \mathrm{c}$ & $1.003 \mathrm{~d}$ & $0.499 \mathrm{c}$ & $0.702 \mathrm{~d}$ & $0.430 \mathrm{~d}$ & $0.584 \mathrm{~d}$ & $2.939 c$ & $4.049 \mathrm{e}$ \\
\hline \multirow[t]{2}{*}{1} & 1 & $1.988 \mathrm{a}$ & $2.337 \mathrm{~b}$ & $1.651 \mathrm{a}$ & $1.813 \mathrm{~b}$ & $1.509 \mathrm{ab}$ & $1.703 \mathrm{a}$ & $9.815 \mathrm{a}$ & $11.567 \mathrm{~b}$ \\
\hline & 2 & $1.724 \mathrm{ab}$ & $1.781 \mathrm{c}$ & $1.236 \mathrm{~b}$ & $1.411 \mathrm{bc}$ & $1.219 \mathrm{bc}$ & $1.232 \mathrm{~b}$ & $7.914 \mathrm{ab}$ & $8.468 \mathrm{c}$ \\
\hline
\end{tabular}

\subsection{Correlations between Classical Firmness and Textural Parameters}

The correlation coefficients (r) between the firmness values measured with the AGROSTA ${ }^{\circledR} 100$ device and the textural parameters issued from the compression tests on the whole fruit, as well as from puncture tests performed on the skin and flesh of both cultivars are illustrated in Figure 7. The correlations between the hand device AGROSTA ${ }^{\circledR} 100$ and the textural parameters issued from the compression tests and the puncture tests on the flesh had r-values ranging from 0.60 to 0.78 , with the exception of the parameters $D_{c}$ (from compression tests), $D_{p}{ }^{m a x}$ and $D_{p}{ }^{1}$ (from puncture tests on the flesh) which showed insignificant r-values. No correlations were observed between the AGROSTA ${ }^{\circledR} 100$ and the parameters related to the skin obtained by puncturing the apricots with a needle $\left(\mathrm{F}_{\mathrm{p}}{ }^{1}, \mathrm{E}_{\mathrm{p}}{ }^{1}, \mathrm{~W}_{\mathrm{p}}{ }^{1}\right.$ and $\mathrm{D}_{\mathrm{p}}{ }^{1}$ ). After the rupture of the skin, positive correlations were, however, observed for most of the parameters (r-values ranging from 0.65 to 0.76 ). Concerning the measurements performed by the three tests of texturometry, correlations were found between the parameters issued from the compression and puncture tests of the flesh. Typical skin parameters issued from the punctures tests were not correlated with the other textural parameters, with the exception of the parameter $\mathrm{E}_{\mathrm{p}}{ }^{1}$ obtained by puncture test on the skin. 


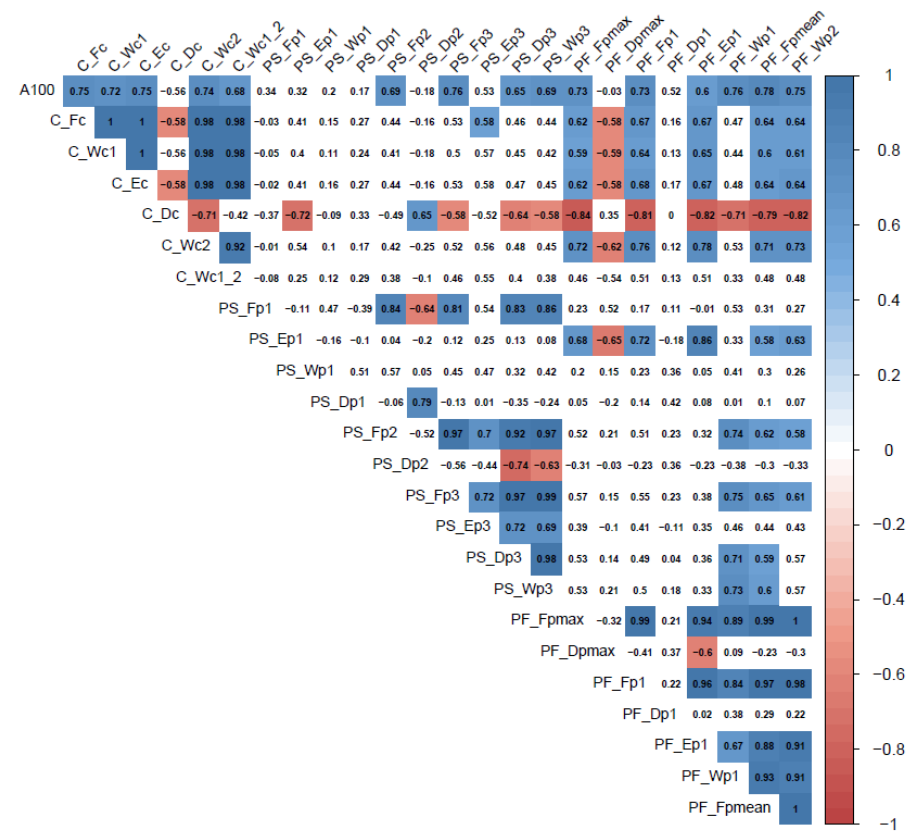

Figure 7. Pearson's correlation coefficients $(p \leq 0.05)$ between firmness measured by AGROSTA ${ }^{\circledR} 100$ (A100) and textural parameters issued from compression test (C), and puncture tests on the skin (PS) and on the flesh (PF). Non-significant values are blank.

\section{Discussion}

Firmness measured with an AGROSTA ${ }^{\circledR} 100$ device was considered as the reference method in this study, as it is the classical method applied by the producers and retailers in Switzerland along the apricot supply chain. This method consists in measuring the force needed to push a flat probe of $0.10 \mathrm{~cm}^{2}$ against the fruit surface. It is easy to use and relatively cheap. In this study, results obtained with this device showed that reducing the temperature of storage limited apricot softening, in particular at $1{ }^{\circ} \mathrm{C}$. This is in line with the study of Aubert et al. [17] in which firmness measurements with the AGROSTA ${ }^{\circledR} 100$ device showed a significant softening of 'Bergeron' apricots stored at $20^{\circ} \mathrm{C}$ compared to $1^{\circ} \mathrm{C}$. This trend was also demonstrated by authors working on other apricot cultivars and using different instruments for measuring firmness: Stanley et al. [11] showed that post-harvest temperature significantly impacted apricot softening based on measurement performed with a Fruit Texture Analyzer (Güss Manufacturing Ltd., Strand, South Africa) and Botondi et al. [18] demonstrated a higher firmness loss of 'Monaco bello' apricots stored at $15{ }^{\circ} \mathrm{C}$ compared to $5{ }^{\circ} \mathrm{C}$ using an Effegi penetrometer (Facchini srl, Alfonsine, Italy). All these results obtained with puncture tests showed comparable influence of low storage temperature on the firmness evolution of apricots. However, these methods are based on one parameter, the maximal force needed to push a probe against the apricot surface (non-destructive) or into the fruit flesh to a determined distance (destructive), preventing detailed description of the influence of the skin and of the flesh on the results.

Measurements performed with the TA-XTplus Texture Analyzer allowed a multi-tests approach that described more precisely the influence of cultivar and storage conditions on different textural properties of the fruit. This instrument gives whole curves from which parameters can be computed. This has the advantage that the evaluation of the influence of the different factors can be done based on the whole curves or only on the extracted parameters. Unlike measurements performed on an AGROSTA ${ }^{\circledR} 100$ device on a small surface of each fruit, compression tests are done on the whole fruit. This test gives information on the viscoelastic properties of the apricot, which is particularly useful for predicting its ability to resist to pressure forces occurring during the post-harvest handling of the fruit (during transport for example). In our study, the plastic deformation $\left(D_{c}\right)$ was influenced by both temperature and duration of storage, in a different manner according to the cultivar. 'Goldrich' apricots 
showed a higher plastic deformation at $20^{\circ} \mathrm{C}$, while this parameter decreased in a more substantial way at $8{ }^{\circ} \mathrm{C}$ for 'Orangered ${ }^{\circledR \prime}$ fruit. Unlike free-fall drop tests used in other studies to evaluate the sensitivity of apricot to mechanical damages [30-32], compression tests have the advantage of being objective as the rate and the percentage of strain are controlled.

The results obtained by puncture tests allowed more precise evaluation of the influence of the storage conditions on the textural properties of the skin and the flesh of 'Goldrich' and 'Orangered ${ }^{\circledR}$, apricot cultivars. A higher force was needed to puncture the skin of 'Goldrich' apricots after a storage at $1{ }^{\circ} \mathrm{C}$ compared to harvest. This may indicate that the skin became tougher under a low temperature, what could contribute greatly to the good storability of this cultivar [33]. Evolution of texture properties related to the skin of 'Orangered ${ }^{\circledR \prime}$ fruit was less impressive, as substantial changes were observed in the flesh for this cultivar depending on the storage temperature. Interestingly, the cultivar 'Orangered ${ }^{\circledR}$, needed higher forces to puncture the flesh compared to 'Goldrich', in both puncture tests of the skin (after skin rupture) and of the flesh, in particular at harvest. Storability of 'Orangered ${ }^{\circledR \prime}$ apricots is, however, lower compared to 'Goldrich', principally due to a higher rate of softening during storage, in line with previous observations [15].

Some of the parameters obtained with the TA-XTplus Texture Analyzer were well correlated with firmness measured by an AGROSTA ${ }^{\circledR} 100$ device, particularly those issued from the compression test and puncture tests of the flesh. The correlations, however, varied between $0 \%$ and $78 \%$ depending on the texture parameter, indicating that the multi-parameter texturometry approach allowed it to describe between $22 \%$ and $100 \%$ of texture variability which was not measured by the classical firmness measurement method. Such additional texture information could help in better understanding the texture variations occurring after harvest. Moreover, texturometry allowed more detailed analysis of the properties of the skin which were not correlated with the firmness obtained with the manual device.

Skin maintains the integrity of the fruit and is an important barrier to the development of fungal diseases. As demonstrated on other fruit [34-36], mechanical properties of the skin greatly influence firmness and resistance to splitting. As splitting is influenced by the genotype [37], measuring textural properties of the skin could be a useful tool not only to improve the post-harvest management of apricots, but also for breeding programs.

\section{Conclusions}

The influence of the cultivar, pre- and post-harvest factors as well as storage conditions on the firmness of an apricot can today be evaluated in detail thanks to the use of different approaches. By combining data issued from a classical manual device and advanced methodologies such as texturometry, this study shows, using 'Goldrich' and 'Orangered ${ }^{\circledR \prime}$ apricot cultivars as models, that varying storage conditions influence firmness, and thereby fruit quality. In regard to that, this study demonstrates that novel methodologies can complement the traditional method well, both in the fruit industry to ensure that optimal fruit quality is obtained and in the research community to better understand the evolution of texture under various storage conditions.

Author Contributions: Conceptualization, S.G.R.; Formal analysis, S.G.R.; Investigation, A.J. and P.-Y.C.; Methodology, S.G.R. and C.C.; Supervision, D.C.; Writing-original draft, S.G.R.; Writing-review and editing, C.C.

Acknowledgments: The authors thank Fabien Rebeaud for his support in writing this paper.

Conflicts of Interest: The authors declare no conflict of interest.

\section{References}

1. FAOSTAT. Available online: http:/ /www.fao.org/faostat/en/\#data/QC (accessed on 12 February 2019).

2. Fruit-Union Suisse. Rapport d'activité 2017. Available online: https:/ / www.swissfruit.ch/sites / default/ files/rapport-dactivite-fruit-union-suisse-2017.pdf (accessed on 12 February 2019). 
3. Barrett, D.M.; Beaulieu, J.C.; Shewfelt, R. Color, flavor, texture, and nutritional quality of fresh-cut fruits and vegetables: Desirable levels, instrumental and sensory measurement, and the effects of processing. Crit. Rev. Food Sci. 2010, 50, 369-389.

4. Salunkhe, D.K.; Deshpande, P.B.; Do, J.Y. Effects of maturity and storage on physical and biochemical changes in peach and apricot fruits. J. Hortic. Sci. 1968, 43, 235-242. [CrossRef]

5. Hewett, E.W. Perceptions of supply chain management for perishable horticultural crops: An introduction. Acta Hortic. 2003, 604, 37-46.

6. Bruhn, C.M.; Feldman, N.; Garlitz, C.; Harwood, J.; Ivans, E.; Marshall, M.; Riley, A.; Thurber, D.; Williamson, E. Consumer perceptions of quality-apricots, cantaloupes, peaches, pears, strawberries, and tomatoes. J. Food Qual. 1991, 14, 187-195.

7. Biale, J.B. Respiration of Fruits; Springer: Berlin, Germany, 1960; Volume 12, pp. 536-592.

8. Hajnal, V.; Szalay, L.; Németh, S.; Ficzek, G.; Bujdosó, G.; Tóth, M. Changes in the fruit texture parameters and composition of apricot cultivars during ripening. Acta Aliment. 2012, 41, 73-82.

9. Stanley, J.; Prakash, R.; Marshall, R.; Schröder, R. Effect of harvest maturity and cold storage on correlations between fruit properties during ripening of apricot (prunus armeniaca). Postharvest Biol. Technol. 2013, 82, 39-50.

10. Infante, R.; Meneses, C.; Defilippi, B.G. Effect of harvest maturity stage on the sensory quality of 'palsteyn' apricot (prunus armeniaca 1.) after cold storage. J. Hortic. Sci. Biotech. 2008, 83, 828-832. [CrossRef]

11. Stanley, J.; Marshall, M.; Ogwaro, J.; Feng, R.; Wohlers, M.; Woolf, A. Postharvest storage temperature impact significantly on apricot fruit quality. Acta Hortic. 2009, 880, 525-532. [CrossRef]

12. Manolopoulou, H.; Mallidis, C.; Karayiannis, I. Storage and processing of apricots. Acta Hortic. 1999, 567-576. [CrossRef]

13. Gabioud Rebeaud, S.; Cotter, P.Y.; Siegrist, J.P.; Christen, D. Influence de la température et de l'atmosphère modifiée sur la qualité des abricots. Revue Suisse Vitic. Arboric. Hortic. 2013, 45, 168-173.

14. Fan, X.; Argenta, L.; Mattheis, J.P. Inhibition of ethylene action by 1-methylcyclopropene prolongs storage life of apricots. Postharvest Biol. Technol. 2000, 20, 135-142.

15. Gabioud Rebeaud, S.; Cotter, P.Y.; Christen, D. Influence du stade de maturité, de la température et du traitement au 1-mcp sur la qualité des abricots. Revue Suisse Vitic. Arboric. Hortic. 2015, 47, 356-362.

16. Camps, C.; Christen, D. On-tree follow-up of apricot fruit development using a hand-held nir instrument. J. Food Agric. Environ. 2009, 7, 394-400.

17. Aubert, C.; Bony, P.; Chalot, G.; Hero, V. Changes in physicochemical characteristics and volatile compounds of apricot (prunus armeniaca 1. Cv. Bergeron) during storage and post-harvest maturation. Food Chem. 2010, 119, 1386-1398. [CrossRef]

18. Botondi, R.; Crisa, A.; Massantini, R.; Mencarelli, F. Effects of low oxygen short-term exposure at 15 degrees on postharvest physiology and quality of apricots harvested at two ripening stages. J. Hortic. Sci. Biotech. 2000, 75, 202-208. [CrossRef]

19. Defilippi, B.G.; Juan, W.S.; Valdés, H.; Moya-León, M.A.; Infante, R.; Campos-Vargas, R. The aroma development during storage of castlebrite apricots as evaluated by gas chromatography, electronic nose, and sensory analysis. Postharvest Biol. Technol. 2009, 51, 212-219. [CrossRef]

20. Chen, L.; Opara, U.L. Texture measurement approaches in fresh and processed foods-A review. Food Res. Int. 2013, 51, 823-835. [CrossRef]

21. Camps, C.; Guillermin, P.; Mauget, J.C.; Bertrand, D. Data analysis of penetrometric force/displacement curves for the characterization of whole apple fruits. J. Texture Stud. 2005, 36, 387-401.

22. Harker, F.R.; Redgwell, R.J.; Hallett, I.C. Texture of fresh fruit. Hortic. Rev 1997, 20, 121-224.

23. Johnston, J.W.; Hewet, E.W.; Banks, N.H.; Harker, F.R.; Hertog, M.L.A.T.M. Physical change in apple texture with fruit temperature: Effects of cultivars and time of storage. Postharvest Biol. Technol. 2001, 23, 13-21. [CrossRef]

24. Yang, Y.; Ma, R.; Zhang, B.; Song, Z.; Zhang, C.; Guo, S.; Yu, M. Different expression analysis in fruit softening and ethylene biosynthetic pathways in peaches of different flesh textures. Hortic. Plant J. 2016, 2, $75-81$.

25. Hallet, I.C.; Harker, F.R. Microscopic investigations of fruit texture. Acta Hortic. 1998, 464, 411-416.

26. Ella Missang, C.; Maingonnat, J.F.; Renard, C.M.G.C.; Audergon, J.-M. Texture variation in apricot: Intra-fruit heterogeneity, impact of thinning and relation with the texture after cooking. Food Res. Int. 2011, 44, 46-53. [CrossRef] 
27. Ella Missang, C.; Maingonnat, J.F.; Renard, C.M.G.C.; Audergon, J.-M. Apricot cell wall composition: Relation with the intra-fruit texture heterogeneity and impact of cooking. Food Chem. 2012, 133, 45-54. [CrossRef]

28. Ayour, J.; Gouble, B.; Reling, P.; Ribas-Agustí, A.; Audergon, J.-M.; Maingonnat, J.-F.; Benichou, M.; Renard, C.M.G.C. Impact of cooking on apricot texture as a function of cultivar and maturity. LWT 2017, 85, 385-389.

29. Mallidis, C.G.; Katsaboxakis, C. Effect of thermal processing on the texture of canned apricots. Int. J. Food Sci. Technol. 2002, 37, 569-572. [CrossRef]

30. De Martino, G.; Vizovitis, K.; Botondi, R.; Bellincontro, A.; Mencarelli, F. 1-mcp controls ripening induced by impact injury on apricots by affecting sod and pox activities. Postharvest Biol. Technol. 2006, 39, 38-47.

31. DeMartino, G.; Massantini, R.; Botondi, R.; Mencarelli, F. Temperature affects impact injury on apricot fruit. Postharvest Biol. Technol. 2002, 25, 145-149. [CrossRef]

32. Di Natale, C.; Filippini, D.; Pennazza, G.; Santonico, M.; Paolesse, R.; Bellincontro, A.; Mencarelli, F.; D'Amico, A.; Lundström, I. Sorting of apricots with computer screen photoassisted spectral reflectance analysis and electronic nose. Sens. Actuat. B-Chem. 2006, 119, 70-77. [CrossRef]

33. Gabioud Rebeaud, S.; Maurer, A.; Cotter, P.Y.; Baumgartner, D.; Christen, D. Influence of temperature, 1-mcp, ma and ca on quality and aroma profiles of 'goldrich' apricots. Acta Hortic. 2015, 1071, 297-302. [CrossRef]

34. Duprat, F.; Loonis, D.; Piétri, E. Mechanical properties of the skin and the flesh of apples au-grotte, m. Int. J. Food Prop. 2001, 4, 149-161.

35. Jackman, R.L.; Stanley, D.W. Influence of the skin on puncture properties of chilled and nonchilled tomato fruit. J. Texture Stud. 1994, 25, 221-230.

36. Lustig, I.; Bernstein, Z. Determination of the mechanical properties of the grape berry skin by hydraulic measurements. Sci. Hortic. 1985, 25, 279-285. [CrossRef]

37. Gülsen, Y.; Dumanoglu, H.; Kunter, B. Fruit cracking in some turkish apricot cultivars. Acta Hortic. 1995, 384, 277-282. [CrossRef]

(C) 2019 by the authors. Licensee MDPI, Basel, Switzerland. This article is an open access article distributed under the terms and conditions of the Creative Commons Attribution (CC BY) license (http:/ / creativecommons.org/licenses/by/4.0/). 